\title{
Development and validation of RP-HPLC method for analysis of multicomponent cough-cold syrup formulation
}

\author{
Branka Ivkovič ${ }^{*}$ Bojan Marković, Sote Vladimirov \\ University of Belgrade - Faculty of Pharmacy, Department of Pharmaceutical \\ Chemistry, Vojvode Stepe 450, Belgrade, Serbia \\ *Corresponding author, e-mail: blucic@pharmacy.bg.ac.rs; phone + 381113951335
}

\section{Summary}

In this study a reversed phase HPLC method for rapid and simultaneous identification and quantification of doxylamine succinate, ephedrine sulfate, dextrometorphane hydrobromide, paracetamole and sodium benzoate in cough-cold syrup formulation was described. Separation was carried out on XTerra ${ }^{\mathrm{TM}} \mathrm{RP} 18$, Waters $(150 \mathrm{~mm} \times 4.6 \mathrm{~mm}$ column, $5 \mu \mathrm{m}$ particle size). For the analysis of investigated substances gradient elution was used employing water, $\mathrm{pH}$ adjusted at 2.5 with $85 \%$ ortophosphoric acid as the mobile phase A and acetonitrile as the mobile phase B. Detection was carried out by UV absorbance at $210 \mathrm{~nm}$ for doxylamine succinate, ephedrine sulfate, dextromethorphane hydrobromide and sodium benzoate and at $270 \mathrm{~nm}$ for paracetamole. The method was validated statistically for selectivity, linearity, precision, accuracy.

Keyword: RP-HPLC, validation of the method, cough-cold syrup formulation 


\section{Introduction}

A cold is usually a mild, self-limiting respiratory infection with a range of viruses, the rhinoviruses and coronaviruses being most frequently involved. Cough is an important physiological protective mechanism, but may also occur as a symptom of an underlying disorder.

Cough and cold preparations, containing various combinations of cough suppressants (e.g. dextrometorphane, codeine phosphate) and expectorants, together with sympathomimetics (e.g. ephedrine or pseudoephedrine hydrochloride), antihistamines (e.g. chlorpheniramine maleate, diphenilhydramine hydrochloride or doxylamine succinate) or analgesics (e.g. acetaminophene) are available. Common formulations of these products are liquids or suspensions and therefore require the addition of preservatives (e.g. benzoic acid, sodium benzoate, methylparabene, propylparabene). The action, properties and structures of these ingredients have been detailed in various references [1]. Several methods have been reported for the determination of ingredients in cough-cold preparations. High-performance liquid chromatography (HPLC) is the commonest approach for assaying of the drugs, because the method is accurate, simple and does not require prior conversion of the drugs to the base form as needed in the gas-liquid chromatographic methods (GLC) [2]. For HPLC assays numerous modes of detection have been employed including ultraviolet [3] conductometric [4], fluorescence [5] or mass spectrometric detection [6]. Most of the reported analytical procedures, like spectrophotometric and derivative spectrophotometric methods [7], gas chromatography (GC) [8], micellar liquid chromatography [9] ion pairing high power liquid chromatography [10], capillary electrophoresis [11], thin layer chromatography (TLC) [12], were validated for the determination of ingredients in cough-cold preparations.

Doxylamine succinate (DS) (2-dimethylaminoethoxy-phenylmethyl-2-picoline succinate salt) is a sedating antihistamine with antimuscarinic and pronounced sedative effects. DS is frequently used in multicomponent preparations for the treatment of cough and cold. [13].

Ephedrine and its salts, e.g. ephedrine sulfate (ES) $((1 R, 2 S)$-2-methylamino-1phenylpropan-1-ol sulfate salts), are used orally, intravenously, intramuscularly and topically for a variety of conditions such as allergic disorders, colds, hypotensive conditions. [14].

Dextromethorphane hydrobromide (DHB) (d-cis-1,2,3-9,10,10a-hexahydro-6methoxy-11-methyl-4H-10, 4a-iminoethanophenanthrene hydrobromide salts) is a cough suppressant used for the relief of non-productive cough; it has a central action on the cough center in the medulla [15]. 
Paracetamole (P) (para-aminophenol derivative) has analgesic and antipyretic properties and weak anti-inflammatory activity. It is also useful in diseases accompanied with pain, discomfort and fever, such as the common cold and other viral infections [16].

Sodium benzoate (SB) has antibacterial and antifungal properties. It is used as preservative in pharmaceutical formulations including oral preparations. Benzoic acid and sodium benzoate are typically employed in concentration of up to $0.2 \%$ and $0.5 \%$, respectively. Sodium benzoate is a common ingredient of cough preparations [1]. All structures on investigated compounds are presented in Figure 1.<smiles>CN(C)CCOC(C)(c1ccccc1)c1ccccn1</smiles>

Doxylamine succinate (DS)<smiles>O=C(O)CCC(=O)O</smiles>

Ephedrine sulfate (ES)

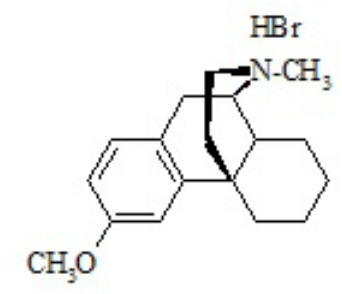

Dextromethorphane hydrobromide<smiles>CC(=O)Nc1ccc(O)cc1</smiles>

Paracetamole<smiles>O=C(O[Na])c1ccccc1</smiles>

Sodium benzoate

\section{Figure 1. Chemical structures of compounds in cough-cold syrup formulation}

Slika 1. Hemijska struktura jedinjenja koja ulaze u sastav sirupa

The aim of this study was to develop reversed phase high performance liquid chromatographic (RP-HPLC) method for the determination of five compounds in syrup formulation (active compounds: doxylamine succinate, ephedrine sulfate, dextrometorphane hydrobromide, paracetamole and preservative sodium benzoate). 


\section{Experimental}

\subsection{Chemicals and reagents}

All chemicals and reagents (acetonitrile, orto-phosphoric acid and water) were HPLC grade. Working standard of doxylamine succinate, ephedrine sulfate, dextromethorphane hydrobromide, paracetamole and sodium benzoate were BP quality and used without further purification.

\subsection{Apparatus}

The chromatographic system Hewlett Packard 1100 (Agilent, Technologies) consisted of HP 1100 pump, HP 1100 UV-VIS detector. UV detection was performed at $210 \mathrm{~nm}$ and $270 \mathrm{~nm}$. The samples were introduced through a Rheodyne injector valve with a $20 \mu \mathrm{L}$ sample loop. All data analysis and chromatogram processing was performed by HP ChemStation software. The $\mathrm{pH}$ measurements were carried out with a Radiometer $\mathrm{pH}$ meter (Copenhagen, Denmark).

\subsection{Standard solutions}

Stock solutions were prepared by dissolving the respective working standard substances in mixture of acetonitrile:water $(20: 80 \mathrm{~V} / \mathrm{V} \mathrm{pH} \mathrm{2.5)}$ to obtain the concentration of $69 \mu \mathrm{g} \mathrm{mL}^{-1}$ for DS, $74 \mu \mathrm{g} \mathrm{mL}^{-1}$ for ES, $125 \mu \mathrm{g} \mathrm{mL}^{-1}$ for DHB, $1259 \mu \mathrm{g}$ $\mathrm{mL}^{-1}$ for $\mathrm{P}$ and $255 \mu \mathrm{g} \mathrm{mL} \mathrm{L}^{-1}$ for $\mathrm{SB}$.

Concentration ranges of standard solutions for calibration curves were from 6.9 $\mu \mathrm{g} \mathrm{mL} L^{-1}$ to $69.0 \mu \mathrm{g} \mathrm{mL}^{-1}$ from DS, from $7.4 \mu \mathrm{g} \mathrm{mL}^{-1}$ to $74.0 \mu \mathrm{g} \mathrm{mL}^{-1}$ for ES, from 12.5 $\mu \mathrm{g} \mathrm{mL} L^{-1}$ to $125.0 \mu \mathrm{g} \mathrm{mL}^{-1}$ for DHB, from $126.0 \mu \mathrm{g} \mathrm{mL}^{-1}$ to $1260.0 \mu \mathrm{g} \mathrm{mL}^{-1}$ for $\mathrm{P}$ and from $25.5 \mu \mathrm{g} \mathrm{mL}^{-1}$ to $255.0 \mu \mathrm{g} \mathrm{mL} \mathrm{L}^{-1}$ for SB.

A mixed working standard solution was prepared in concentrations of $27.4 \mu \mathrm{g}$ $\mathrm{mL}^{-1}$ for DS, $29.6 \mu \mathrm{g} \mathrm{mL}^{-1}$ for ES, $49.8 \mu \mathrm{g} \mathrm{mL}^{-1}$ for DHB, $252.0 \mu \mathrm{g} \mathrm{mL}^{-1}$ for $\mathrm{P}$ and 102.0 $\mu \mathrm{g} \mathrm{mL} \mathrm{m}^{-1}$ for SB.

\subsection{Sample preparation}

Sample solution was prepared by adding $5 \mathrm{~mL}$ of syrup formulation to a $50 \mathrm{~mL}$ volumetric flask along with around $30 \mathrm{~mL}$ of mixture of acetonitrile : water $(20: 80 \mathrm{v} / \mathrm{v}$ $\mathrm{pH}$ 2.5). This degas for $10 \mathrm{~min}$. The volumetric flask was filled to the mark with mixture of acetonitrile:water $(20: 80 \mathrm{v} / \mathrm{v} \mathrm{pH} 2.5)$ and the resulting solution was filtered trough $0.45 \mu \mathrm{m}$ nylon membrane filter. Sample solution for determination $\mathrm{P}$ was preparing by adding $5 \mathrm{~mL}$ of syrup formulation to $25 \mathrm{~mL}$ volumetric flask. 


\subsection{Chromatographic conditions}

In the presented investigation the best separation of these five compounds was achieved using XTerra ${ }^{\mathrm{TM}}$ column $150 \mathrm{~mm}$ x $4.6 \mathrm{~mm}, 5 \mu \mathrm{m}$ particle size. This column differs from the other $\mathrm{C}_{18}$ columns by methyl groups attached to free silanol groups. In that way duration of the separation is shortened and peak symmetry improved. For the separation and determination of DS, ES, DHB, P and SB in cough-cold syrup formulation the best results were obtained using gradient elution system. Mobile phase A was water, $\mathrm{pH}$ adjusted at 2.5 with $85 \%$ orto phosphoric acid. Mobile phase B was acetonitrile. Method development led to the mobile phase and flow rate timetable shown in the Table I. Time for analysis was less than $8 \mathrm{~min}$.

Table I Mobile phase time table

Tabela I Program gradijentnog eluiranja

\begin{tabular}{|c|c|c|c|}
\hline Time (min) & Mobile phase A (\%) & Mobile phase B (\%) & Flow rate (mL/min) \\
\hline 0 & 90 & 10 & 1 \\
\hline 2.5 & 90 & 10 & 1 \\
\hline 3.5 & 80 & 20 & 1.5 \\
\hline 6.5 & 80 & 20 & 1.5 \\
\hline 8.5 & 90 & 10 & 1 \\
\hline
\end{tabular}

\section{Results and discussion}

The choice of the method depends on factors such as the nature of the drug, the complexity of the sample and the intended use. In this study the conditions were influenced by the physical-chemical properties of investigated substances such as solubility, polarity, UV absorption and interference.

Influence of the mobile phase composition on the separation of DS, ES, DHB, P and SB was investigated following retention times and peak symmetry. It was important to obtain the most appropriate conditions when: a) DS and ES were satisfactory separated, b) DS and ES separated from the peak of the excipients and c) DHB was not retained for a very long time that affected peak shape. Changes in mobile phase strength by increasing or decreasing content of acetonitrile in mobile phase had a great influence on chromatographic behavior of these substances. The retention times of all compounds decreased with increase of acetonitrile content, where there was a parallel decrease in 
the polarity of the mobile phase. Moreover, the rate of decrease was higher for drugs with higher molecular mass, such as DS and DHB, which are also more bulky and less polar nature, compared with those having lower molecular mass and being more polar, such as ES, P and SB. The results indicate that hydrophobic interaction of the drugs with the column was one of the essential operating mechanisms for the above column separation.

Identification was based on retention times by comparison with commercial standards. Optimal retention times for all compounds are shown in the Table II.

Table II The retention times of the compounds in the cough-cold syrup

Tabela II Retenciona vremena ispitivanih analita u sirupu

\begin{tabular}{|l|c|}
\hline Compound & Retention time (min) \\
\hline Doxylamine succinate & 2.22 \\
\hline Ephedrine sulfate & 2.39 \\
\hline Dexamethasone hydrobromide & 6.61 \\
\hline Paracetamole & 2.98 \\
\hline Sodium benzoate & 5.42 \\
\hline
\end{tabular}

There was baseline resolution of all the drugs with the exception of DS-ES, were the values for resolution factor was about 1 . In generally all drugs could be determined simultaneously in a single chromatographic run. The concentrations were adjusted so that peak areas were not too high and peaks were not obscuring a neighboring one.

After establishing the optimal conditions proposed RP-HPLC method was validated. Selectivity towards the other excipients in the syrup formulation, linearity, accuracy and precision were investigated.

Selectivity of an analytical method is defined as its ability to measure accurately an analyte in the presence of interferences, such as synthetic precursors, exipients and known degradation products that may be expected to be present in the sample matrix. Analyzing the chromatograms obtained for the laboratory mixture and excipient good selectivity of the developed RP-HPLC method was shown.

Resolution between the DS and ES as well as DS and compound from excipient $\left(\mathrm{t}_{\mathrm{R}}=2.037 \mathrm{~min}\right)$ is satisfactory $(\mathrm{Rs}=1.5)$.

Linear relationships of peak area over the mentioned concentration ranges for DS, ES, DHB, P and SB were obtained. The important parameters of calibration curves: 
slope $(a)$, intercept $(b)$, correlation coefficient $(r)$, standard deviation of the slope $\left(S_{a}\right)$ and standard deviation of the intercept $\left(S_{b}\right)$ are presented in Table III.

Table III Basic attributes of calibration curve for DS, ES, DHB, P and SB

Tabela III Podaci za linearnu regresionu analizu za DS, ES, DHB, P i SB

\begin{tabular}{|l|c|c|c|c|c|}
\hline & $\begin{array}{c}\text { Doxylamine } \\
\text { succinate }\end{array}$ & $\begin{array}{c}\text { Ephedrine } \\
\text { sulfate }\end{array}$ & $\begin{array}{c}\text { Dexamethasone } \\
\text { hydrobromide }\end{array}$ & Paracetamole & $\begin{array}{c}\text { Sodium } \\
\text { benzoate }\end{array}$ \\
\hline Data points $(\mathrm{N})$ & 5 & 5 & 5 & 5 & 5 \\
\hline $\begin{array}{l}\text { Calibracion } \\
\text { equation } \\
(\mathrm{y}=\mathrm{ax}+\mathrm{b})\end{array}$ & $\mathrm{y}=37.69 \mathrm{x}+36.14$ & $\mathrm{y}=95.92 \mathrm{x}+39.77$ & $\mathrm{y}=150.58 \mathrm{x}+23.486$ & $\mathrm{y}=474.88 \mathrm{x}+13.24$ & $\mathrm{y}=67.54 \mathrm{x}+16.64$ \\
\hline $\begin{array}{l}\text { Correlation } \\
\text { coefficient }(\mathrm{r})\end{array}$ & 0.9990 & 0.9998 & 0.9993 & 0.9994 & 0.9999 \\
\hline $\begin{array}{l}\text { Standard error } \\
\text { of intercept } \\
\left(\mathrm{S}_{\mathrm{b}}\right)\end{array}$ & 1.0 & 0.41 & 0.52 & 0.25 & 0.07 \\
\hline $\begin{array}{l}\text { Standard error } \\
\text { of slope }\left(\mathrm{S}_{\mathrm{a}}\right)\end{array}$ & 46.9 & 20.25 & 43.54 & 179.01 & 12.07 \\
\hline $\begin{array}{l}\text { Significance of } \\
\text { intercept }\left(\mathrm{t}_{\mathrm{a}}\right)\end{array}$ & 0.8 & 4.74 & 3.46 & 2.65 & 5.59 \\
\hline
\end{tabular}

The precision and accuracy of the proposed method was investigated and results are presented in Table IV. 
Table IV Precision and accuracy results

Tabela IV Rezultati za tačnost i preciznost metode

\begin{tabular}{|c|c|c|c|c|}
\hline Compound & $\begin{array}{c}\text { Concentration } \\
(\mu \mathrm{g} / \mathrm{mL})\end{array}$ & $\begin{array}{c}\text { Found } \\
(\mu \mathrm{g} / \mathrm{mL})\end{array}$ & $\begin{array}{l}\text { CV } \\
(\%)\end{array}$ & $\begin{array}{c}\mathrm{R} \\
(\%)\end{array}$ \\
\hline \multirow{3}{*}{ Doxylamine succinate } & 13.7 & $13.6 \pm 0.0001^{\mathrm{a}}$ & 0.7 & 99.27 \\
\hline & 27.4 & $27.3 \pm 0.0001^{\mathrm{a}}$ & 0.4 & 99.63 \\
\hline & 54.8 & $55 \pm 0.0004^{\mathrm{a}}$ & 0.72 & 100.36 \\
\hline \multirow{3}{*}{ Ephedrine sulfate } & 14.8 & $14.8 \pm 0.0001^{\mathrm{a}}$ & 0.67 & 100 \\
\hline & 29.6 & $29.5 \pm 0.0001^{\mathrm{a}}$ & 0.34 & 99.66 \\
\hline & 59.1 & $59.2 \pm 0.0003$ & 0.51 & 100.17 \\
\hline \multirow{3}{*}{$\begin{array}{l}\text { Dextromethorphane } \\
\text { hydrobromide }\end{array}$} & 24.9 & $24.6 \pm 0.0002^{\mathrm{a}}$ & 0.81 & 100 \\
\hline & 49.8 & $50 \pm 0.0002^{\mathrm{a}}$ & 0.26 & 100.40 \\
\hline & 99.6 & $97.4 \pm 0.0009^{\mathrm{a}}$ & 0.92 & 97.79 \\
\hline \multirow{3}{*}{ Paracetamole } & 252 & $251 \pm 0.0002^{\mathrm{a}}$ & 0.1 & 99.60 \\
\hline & 504 & $507 \pm 0.0002^{\mathrm{a}}$ & 0.32 & 100.60 \\
\hline & 756 & $756 \pm 0.0002^{\mathrm{a}}$ & 0.1 & 100 \\
\hline \multirow{3}{*}{ Sodium benzoate } & 51 & $51 \pm 0.0005^{\mathrm{a}}$ & 0.1 & 100 \\
\hline & 102 & $102 \pm 0.0001^{\mathrm{a}}$ & 0.1 & 100 \\
\hline & 204 & $204 \pm 0.0002^{\mathrm{a}}$ & 0.09 & 100 \\
\hline
\end{tabular}

${ }^{\mathrm{a}} \mathrm{SD}$ - Standard Deviation $(\mathrm{n}=10)$

The results for standard deviation (SD), coefficient of variation (CV) and Recovery $(\mathrm{R})$ show that the described RP-HPLC method is precise and can be used for the routine analysis of dosage forms that contain DS, ES, P, SB and DHB.

The contents of the five drugs in the cough-cold syrup were determined by the proposed method and the important statistical values, such as coefficient of variation (CV) and Recovery (R), are given in Table V. The chromatograms of standard mixture and cough-cold syrup are shown in Figure 2 and Figure 3, respectively. 
Table $\mathbf{V}$ The results of the content determination in sirup $(n=10)$

Tabela V Rezultati određivanja sadržaja komponenata u sirupu

\begin{tabular}{|l|l|l|l|}
\hline \multicolumn{1}{|c|}{ Compound } & \multicolumn{1}{|c|}{$\begin{array}{c}\text { Label value } \\
(\mathbf{g} / \mathbf{1 0 0 m L})\end{array}$} & $\begin{array}{c}\text { Average values } \\
(\mathbf{g} / \mathbf{1 0 0} \mathbf{m L})\end{array}$ & $\begin{array}{c}\text { Found } \\
\mathbf{( \% )}\end{array}$ \\
\hline Doxylamine succinate & 0.025 & 0.0236 & 94.50 \\
\hline Ephedrine sulfate & 0.0267 & 0.0264 & 98.79 \\
\hline Dextromethorphane hydrobromide & 0.050 & 0.051 & 102.48 \\
\hline Paracetamole & 2.0 & 2.004 & 100.19 \\
\hline Sodium benzoate & 0.100 & 0.103 & 103.37 \\
\hline
\end{tabular}
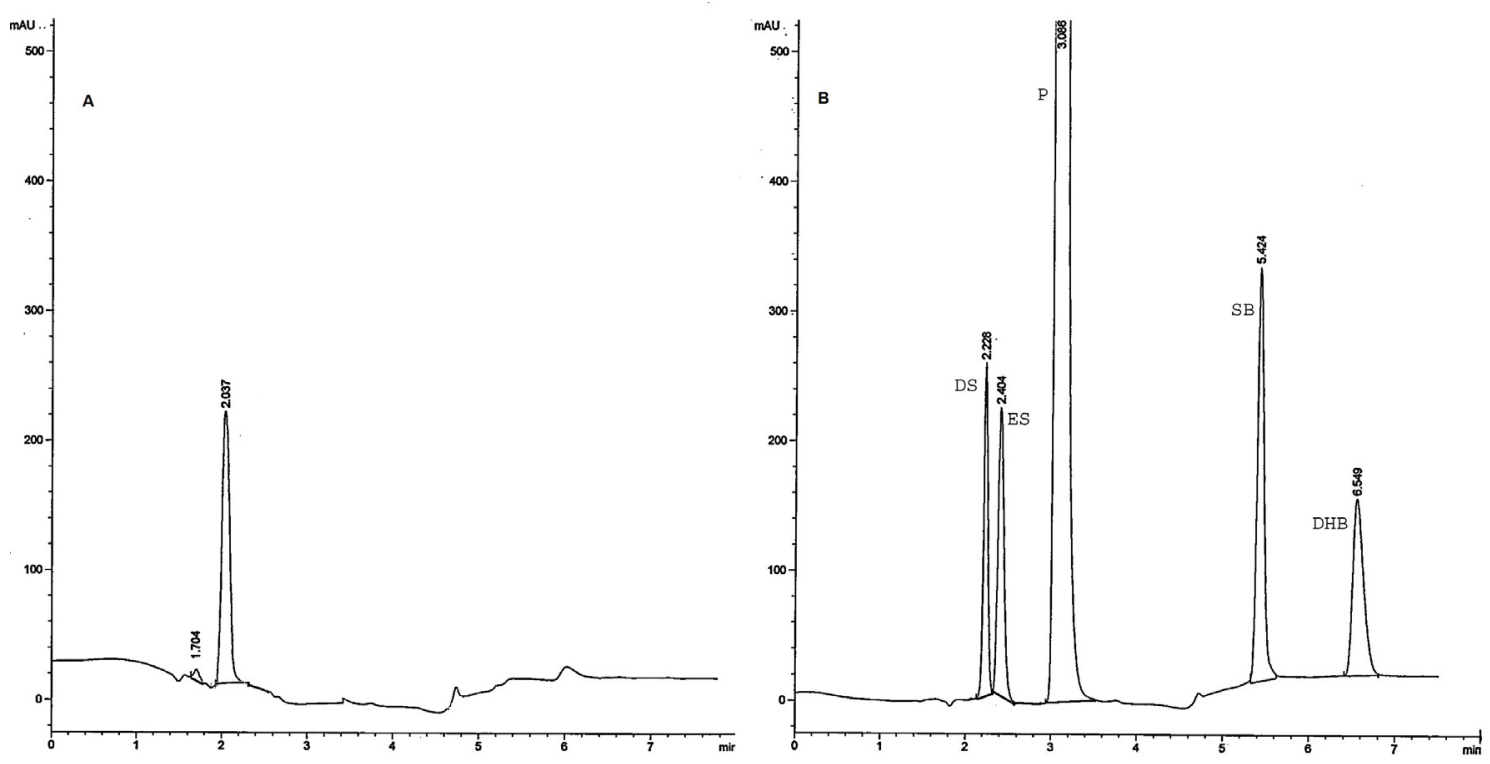

Figure 2. HPLC chromatograms: A) placebo mixture and B) all compounds in standard solution: DS-doxylamine succinate, ES-ephedrine sulfate, P-paracetamole, SBsodium benzoate, DHB-dextromethorphane hydrobromide; detection was carried out at a $\lambda=210 \mathrm{~nm}$

Slika 2. HPLC hromarogrami: A) placebo smeše i B)smeše rastvora standarnih supstanci: DS-doksilamin-sukcinat, ES-efedrin-sulfat, P-paracetamol, SB-natrijum benzoat, DHB-dekstrometorfan hidrobromid; UV detekcija na 210 nm 


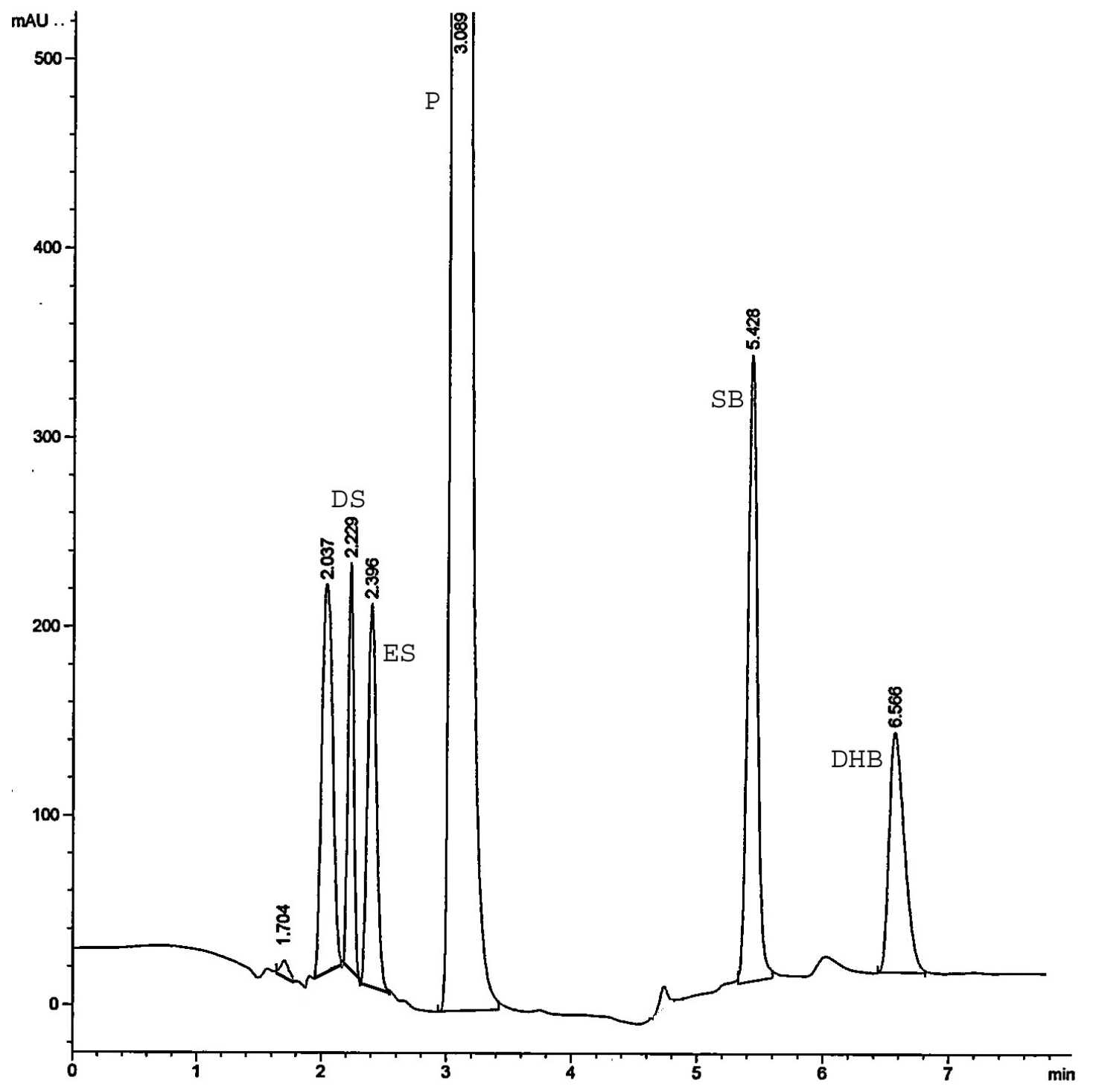

Figure 3. HPLC chromatogram of all compounds in cough-cold syrup formulation: DSdoxylamine succinate, ES-ephedrine sulfate, P-paracetamole, SB-sodium benzoate, DHB-dextromethorphane hydrobromide; detection was carried out at a $\lambda=210 \mathrm{~nm}$

Slika 3. HPLC hromatogram analiziranog rastvora sirupa za kašalj: DS-doksilaminsukcinat, ES-efedrin-sulfat, P-paracetamol, SB-natrijum benzoat, DHBdekstrometorfan hidrobromid; UV detekcija na $210 \mathrm{~nm}$ 
Determination of P (Figure 4) was performed at $270 \mathrm{~nm}$ because the response at $210 \mathrm{~nm}$ was too high, so the precision of determination was not satisfactory.

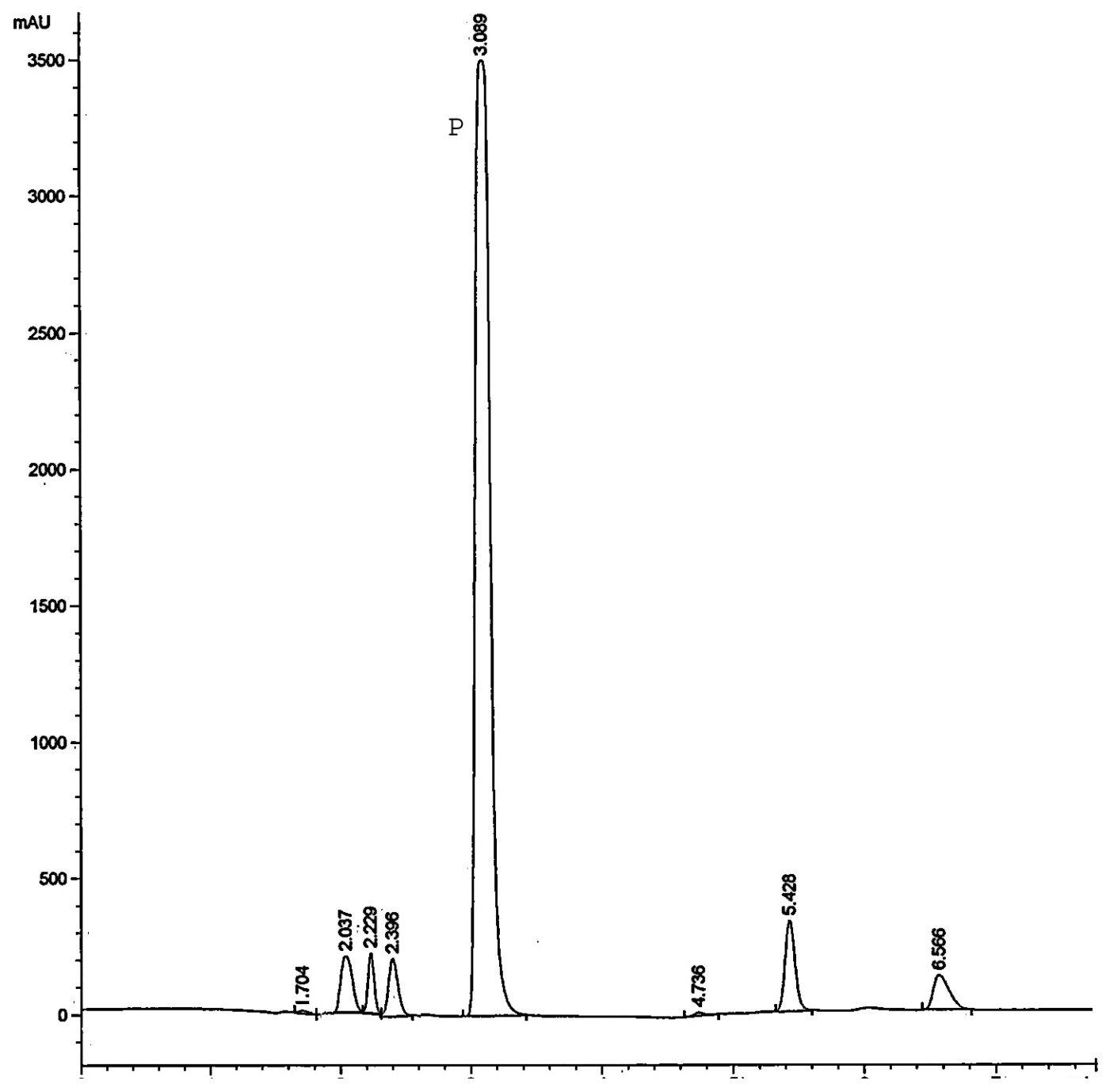

Figure 4. Chromatogram of all compounds in cough-cold syrup formulation; detection was carried out at a $\lambda=270 \mathrm{~nm}$

Slika 4. Hromatogram analiziranog rastvora sirupa detektovan na $270 \mathrm{~nm}$ 


\section{Conclusions}

The proposed gradient reverse-phase HPLC method enables simultaneous determination of DS, ES, DHB, P and SB because a good separation and resolution of the chromatographic peaks was achieved. Method is applicable for a qualitative and quantitative analysis of the cough-cold syrup formulation. The obtained results are in a good agreement with the declared contents. The developed RP-HPLC method is useful for simple, rapid, accurate and precise routine assay of syrup formulation.

\section{Acknowledgement}

This work was partially supported by the Ministry of Education, Science and Technological Development of the Republic of Serbia (Grants no.172041).

\section{References}

1. Group of authors (2009) Sodium benzoate, In: Sweetman SC (ed.), Martindale The complete drug reference, $36^{\text {th }}$ ed., London, p. 1630

2. Harsono T, Yuwono M, Indrayanto G. Simultaneous determination of some active ingredients in cough and cold preparations by gas chromatography, and method validation. J.AOAC 2005; 88(4):1093-8.

3. Hood DJ, Cheung HY. A chromatographic method for rapid and simultaneous analysis of codeine phosphate, ephedrine $\mathrm{HCl}$ and chlorpheniramine maleate in cough-cold syrup formulation. J Pharm Biomed Anal 2003;30(5):1595-601.

4. Lau OW, Mok CS. High-performance liquid chromatographic determination of active ingradients in coug-cold syrups with indirect conductometric detection. J Chromatog A 1995, 693(1):45-54.

5. Bartoletti RA, Belpaire FM, Rosseel MT. High-performance liquid chromatography determination of dextromethorphan and its metabolites in urine using solid-phase extraction. J Pharm Biomed Anal 1996, 14(8-10):1281-86.

6. Eichhold TH, Quijano M, Seibel WL, Cruze CA, Dobson RLM, Wehmeyer KR. Highly sensitive high-performance liquid chromatographic-tandem mass spectrometric method for the analysis of dextromethorphan in human plasma. J Chromatog B Biomed Sci Appl 1997, 698(1-2):147-54. 
7. Dogan HN, Duran A. Simultaneous spectrophotometric determination of aspirin, acetaminophen and ascorbic acid in pharmaceutical preparations. Pharmazie 1998, 53:781-4.

8. Raj SV, Kapadia SU, Argekar AP. Simultaneous determination of pseudoephedrine hydrochloride and diphenhydramine hydrochloride in cough syrup by gas chromatography (GC). Talanta 1998, 46(1):221-25.

9. Gil-Agustí M, Monferrer-Pons L, García-Alvarez-Coque MC, Esteve-Romero J. Determination of active ingredients in cough-cold preparations by micellar liquid chromatography. Talanta 2001, 54(4):621-30.

10. Paciolla MD, Jansen SA, Martellucci SA, Osei AA.A fast and efficient determination of amines and preservatives in cough and cold liquid and suspension formulations using a single isocratic ion-pairing high power liquid chromatography method. J Pharm Biomed Anal 2001, 26(1):143-49.

11. Zhang L, Hu Q, Chen G, Fang Y. Simultaneous determination of the active ingradients in composite pseudoephedrine hydrochloride tablets by capillary electrophoresis. Anal Chem Acta 2000, 424(2): 257-62.

12. Yaqing Z, Shourong H, Qingshe L. TLC-UV spectrophotometry of fast-acting syrup for cold. Zhongguo Yiyao Gongyl Zazhi 1991, 22(11):506-7.

13. Vida J, Yevich J. Sedative-Hypnoties, In: Abraham DJ (ed), Burger's Medicinal Chemistry and Drug Discovery, Volume 6: Nervous System agents, $6^{\text {th }}$ ed., New Jersey, 2003, p. 212-4.

14. Buss AD, Cox B, Waigh RD. Natural Products as Leads for New Pharmaceuticals, In: Abraham DJ (ed), Burger's Medicinal Chemistry and Drug Discovery, Volume 1: Drug Discovery, $6^{\text {th }}$ ed., New Jersey, 2003, p. 884-6.

15. Buckett BJ, Terra SG, Walker J. Single nucleotide polymorphisms and pharmacogenomicsindividually designed drug therapy, In: Abraham DJ (ed), Burger's Medicinal Chemistry and Drug Discovery, Volume 4: Antocoids, Diagnostics and Drug from New Biology, $6^{\text {th }}$ ed., New Jersey, 2003, p. 627.

16. Group of authors Paracetamole, In: Sweetman SC (ed.), Martindale The complete drug reference, $36^{\text {th }}$ ed., London, (2009) p. 108. 


\title{
Razvoj i validacija RP-HPLC metode za analizu višekomponentnog sirupa za kašalj
}

\author{
Branka Ivkovič́, Bojan Marković, Sote Vladimirov
}

Univerzitet u Beogradu - Farmaceutski fakultet, Katedra za Farmaceutsku hemiju, Vojvode Stepe 450, Beograd, Srbija

*Autor za prepisku, e-mail: blucic@pharmacy.bg.ac.rs; telefon + 381113951335

\section{Kratak sadržaj}

U ovom radu opisana je brza, efikasna, ekonomična reverzno fazna HPLC metoda za identifikaciju i određivanje doksilamin-sukcinata, efedrin-hidrohlorida, dekstrometorfanhidrobromida, paracetamola kao aktivnih komponenti i natrijum-benzoata kao konzervansa $\mathrm{u}$ sirupu za kašalj. Razdvajanje komponenata, njihova identifikacija i određivanje postignuto je na C18 stacionarnoj fazi (XTerra ${ }^{\mathrm{TM}} \mathrm{RP} 18$, Waters $(150 \mathrm{~mm}$ x 4,6 mm, $5 \mu$ m veličine čestica) uz gradijentno eluiranje sa mobilnom fazom koju čine voda (čiji je pH podešen na 2,5 sa ortofosfornom kiselinom) i acetonitril kao organski rastvarač. Za detekciju ispitivanih jedinjenja korišćen je UV/VIS detektor podešen na $210 \mathrm{~nm}$ (doksilamin sukcinata, efedrin-hidrohlorida, dekstrometorfan-hidrobromida i natrijum-benzoata) tj. $270 \mathrm{~nm}$ (paracetamol). Kako je definisana metoda namenjena za identifikaciju i određivanje aktivnih supstanci i konzervansa $u$ sirupu za kašalj, od parametara validacije ispitani su: selektivnost/specifičnost, linearnost, tačnost i preciznost. Svaki od parametara je statistički potvrđen. Dobijene vrednosti statističkih parametara ( $r \geq 0,999, \mathrm{CV} \leq 2 \%$ i Recovery od $98 \%$ - $102 \%$ ) ukazuju da je definisana RPHPLC metoda pogodna za identifikaciju i određivanje doksilamin-sukcinata, efedrinhidrohlorida, dekstrometorfan-hidrobromida, paracetamola i natrijum-benzoata u sirupu za kašalj.

Ključne reči: RP-HPLC, sirup za kašalj, validacija metode 